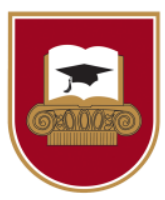

Vadyba

Journal of Management

2020, № 1 (36)

ISSN 1648-7974

\title{
TRENDS IN FASHION RETAIL - GLOBAL EXPANSION AND CENTRALIZATION OF THE MOST COMPETITIVE PLAYERS
}

\author{
Gyorgy Gonda ${ }^{1}$, Maria Fekete Farkas ${ }^{2}$, PhD \\ ${ }^{1}$ Szent István University, Doctoral School of Management and Business Administration \\ ${ }^{2}$ Szent István University Faculty of Economics and Social Sciences
}

\begin{abstract}
This paper focuses on the situation of fashion retail sector in the Central and Eastern European countries and examines the changes in the sector after the transition from central plan to market economic system. In addition to providing an overview of the strong concentration processes in Western European fashion trade, our results show that in the Central and Eastern European countries these processes have been completed much faster. The domestic fashion retail companies have been facing strong competition arising from both the Western and Asian countries which has brought a structural change in the sector in the past two decades. In this paper we show a snapshot of the current situation of the brands' occupation in the Hungarian premium retail locations. We find that the majority of the leading, top 20 global fashion networks are present and dominate the market in Hungary. We have identified the integration of the whole supply chain, the rapid reaction to customer demand changes and innovation as major competitive factors. The conclusion drawn from the study is that in this highly competitive area where the new international comers are dominated only those retail stores can survive, which have long experience in this business area, has own production background and are open to innovative solutions.
\end{abstract}

KEY WORDS. fashion retail, shopping streets, concentration, globalization.

\section{Introduction}

The modern fashion industry acknowledged by brands and names of the creators, started in the 19th century when designers sew his/her label into the garments for the first time. Due to the industrial revolution, the manufacturing of confectionary began in the 19th century already and from that time the clothing was not necessary tailored for the clients made-to-measure.

From the mid of this century, the Haute Couture came alive in Paris. The famous fashion designers created their art works for the Western consumers and inspired other designers' works in the other parts of the world (Steele, 1988; Ochkovskaya, 2018).

After the world wars, the great designers showed up in the West; Dior, Yves Saint Laurent, Balenciaga, Givency and Chanel drove the demand in the luxury fashion among other great names. While economies started booming in the West, communism arrived to the East. (Simonics, 2015). In the socialist block, the communist ideology expressed equality and collectivization, and fashion had no role apart from creating cheap, and accessible wear for everyone. The 70 's brought some changes, the socialist system allowed the fashion to function in order to increase the satisfaction level of the people. From this time, the Eastern-European designers began to come up with their collections which were mostly inspired by the Western designers works. The garments were made in the socialist countries and manufactured in state companies and sold in the state stores.

After the political and economic transition, the fashion sector was liberated and the young generation who dreamed of the Western lifestyle started to purchase Western branded items which they could afford to pay for. The foreign, Western-European and American brands' settlement began in the Central and Eastern Europe through importers, agents, retailers and also the manufacturing mother companies, the brand owners opened their first monolabel brand stores. In a decade, significant part of the less competitive local players were pushed out from the premium retail locations by the very prestigious old brands (Smith at al., 2014). While the competition increased and the growth rate of demand for fashion goods decreased in the 1990's in the Western markets, the gates opened to the East and the players started their extension there. The paper analyses these market dynamics in Hungary focusing on the premium fashion retail locations.

In the next chapters, we present the materials and methodology used in this research and examine to what extent the world's strongest brands and fashion multinational conglomerates could conquer the best retail locations through the examples of the high streets of Budapest, Hungary.

\section{Methodology}

Data was collected from all major fashion retailer firms in the Váci, Deák Ferenc and Andrássy high streets of Budapest. The primary data was collected during February-April 2019 via personal visits to the retail stores, including a few semi-structured interviews. The companies' actual and historical financial data, ownership structure and location information was obtained from OPTEN company database system. Other sources of secondary data included data from annual reports, public company databases, and webpages of the companies. For the purpose of evaluation and analysis, the collected data were structured under the name of company, brand(s) of retail unit, type of company, ownership structure of 
company, history of company, history of brand and turnover figures of the operator company.

\section{Fashion industry globally and in Hungary}

\section{The biggest players in the global Fashion industry}

The fashion industry market share was $4 \%$ and its value reached 385.7 billion US dollars globally in 2017 . The luxury goods market generated a major share of around 339.4 billion dollars. The fashion industry has been witnessing a strong concentration of the major players in the last 50 years and in 2010, the top 20 companies accounted for 70 percent in the global economic profit according to McKinsey \& Company.

In 2018, the top 20 companies dominate world's fashion industry and these companies account for $97 \%$ of global economic profit in the sector (McKinsey, 2019). The list and position of the top 20 companies is shown in Figure 1. As it can be seen, most of them are being in the global leader position constantly in the past decade.

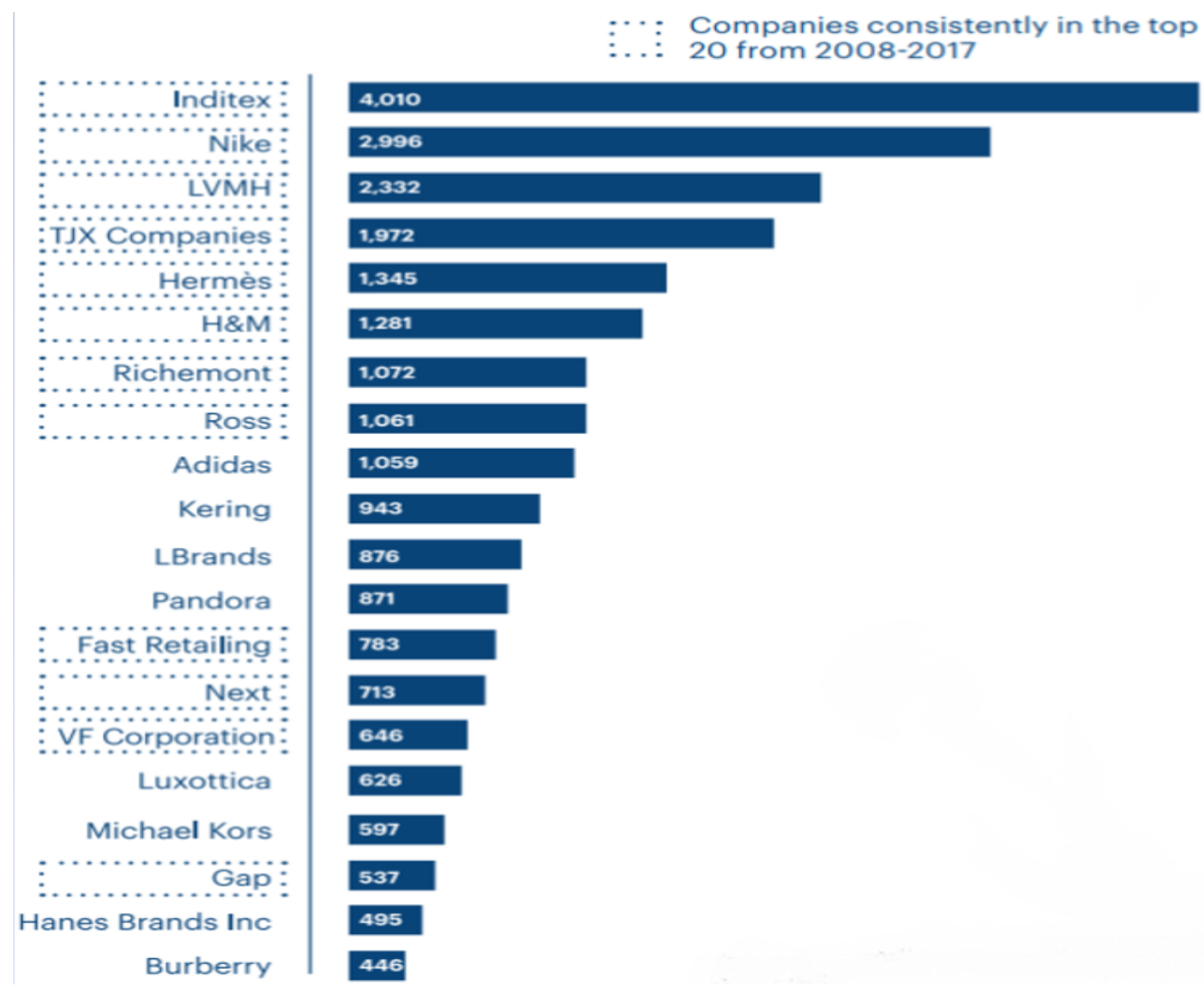

Fig. 1. The top 20 major players in fashion industry by economic profit in \$ US source: McKinsey Global Fashion Index (MKGF), 2018

The biggest players operate with several brands. Some of them grew their own portfolio like Inditex Group, which not only has Zara, but also sell Stradivarius, Bershka, Massimo Dutti and Oysho although many customers don't connect with them. Some of the most successful traditional brands' owners have been acquiring many other successful brands. It is worth to list the acquisitions of the LVMH Group as an example to see the level of concentration in the global fashion industry:

1987: Louis Vuitton. 1988: Givenchy. 1993: Berluti. 1993: Kenzo. 1994: Guerlain. 1996: Céline. 1996: Loewe. 1997: Marc Jacobs. 1997: Sephora. 1999: Thomas Pink. 1999: Tag Heuer. 2000: Emilio Pucci. 2000: Rossimoda. 2001: Fendi. 2001: DKNY. 2009: EDUN. 2010: Moynat. 2011: Bulgari. 2013: Loro Piana. 2013: Nicholas Kirkwood. 2013: J.W. Anderson. 2015:
Repossi. 2016: Rimowa. 2017: Christian Dior (LMVH, 2019).

The Kering group has Gucci, Yves Saint Laurent, Balenciaga and several other famous brands. All these companies have a long history in this business with great networking and experience, owning brands which have great value built up over decades. These strong fashion companies entered the Eastern European markets after the change and immediately created a highly competitive arena for the smaller, younger and inexperienced companies which were mostly formed at the end of the socialist times. An interesting fact is that not only fashion brands have built up themselves so strong, but also the department stores which sell other brands products and the store name have become popular and valuable brands, like Neimann Marcus for example, although they could not make it to the top 20 . 


\section{Hungarian premium retail locations}

The premium retail locations can be described with these attributes: the highest rent, the highest footfall and the most important - the highest spending. These factors are in strong correlation with each other, of course where the footfall is higher, there will be more sales, thus there will be more spending - and this sets the rent level in the market.

In Hungary, the top locations can be found in the capital city of Hungary, in the high streets of Budapest, which are the most visited places by the tourists.

According to the latest market research of Cushman and Wakefield (Cushman and Wakefield, 2019), these are the top premium streets and locations in Budapest, ordered by the average monthly rent for a unit size 100$200 \mathrm{~m} 2$.

The Váci street is the high street of the capital and the most visited street by the tourists. Right next to Váci street is Deák Ferenc street, named and referred as "Fashion street" - very small in terms of area, but a busy street. There is a third street called Andrássy street, the place traditionally for the most luxurious brands but with much less footfall (number of pedestrians who walk right in front of the store) than that of Váci and Fashion street (Fig. 2.).

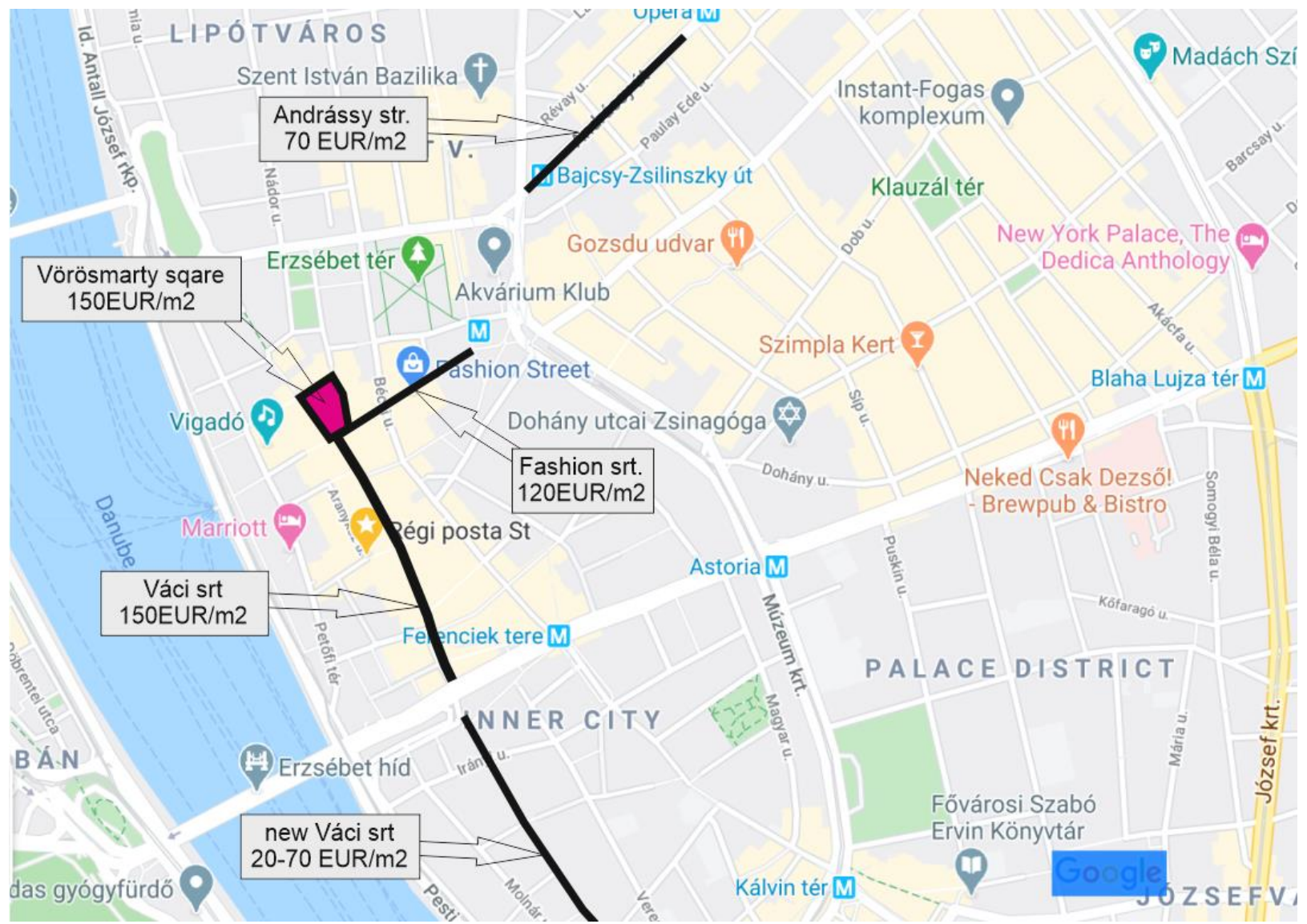

Fig. 2. The shopping streets of Budapest

source: own editing; Google Maps (2020)

Váci street has two different sections, one is the most frequented, premium location, from Kossuth Lajos street to Vörösmarty square. The other section of the street is not considered as a prime location ("New" Váci street). At Andrássy street, we are only taking the prime location into consideration, which lies from Oktogon square to Bajcsy-Zsilinszky street. The actual average rent figures shown in Table 1 are corresponding to these parts of the streets (Cushman and Wakefield, 2019)
Table 1: Average monthly rent in the high streets of Budapest.

\begin{tabular}{|lc|}
\hline Street name & Rent (price/m2/month) \\
\hline Váci stree & 150 EUR \\
\hline $\begin{array}{l}\text { Fashion Street (Deák } \\
\text { Ferenc Street) }\end{array}$ & 120 EUR \\
\hline Andrássy street & 70 EUR \\
\hline
\end{tabular}


In this study we mainly focus on the highest rent street retail spaces and the most prestigious locations without including the shopping centers despite the presence of many malls whose rents are comparable to that of the shopping streets. In the next chapter we depict the actual snapshot of the brand occupation in these premium locations.

\section{Brands' occupation of the premium retail locations in Budapest}

According to our research which was carried out between September and October of 2019, we found 29 fashion clothing retail stores in Váci street, 14 stores in Fashion street and 31 fashion retail stores in Andrássy street. Jewellery stores were excluded in this research.

We examined the retail units' operator firm's company structure, looking for the connection between the operator firm and the brand ownership, investigated the end owners, the parent companies if there were any. We stated if the operator company was the brand owner itself, or a daughter company of a manufacturer brand owner, or a reseller. The results are given in Table 2.

Table 2: fashion retail stores in the high streets of Budapest

\begin{tabular}{ccccc}
\hline Váci Street & $\begin{array}{c}\text { Number } \\
\text { of shops }\end{array}$ & Váci + Fashion + Andrássy street & $\begin{array}{c}\text { Number } \\
\text { of shops }\end{array}$ \\
\hline Number of clothing stores in total & 29 & Number of clothing stores in total & 74 \\
\hline $\begin{array}{l}\text { Manufacturer unit operated } \\
\text { by the brand owners }\end{array}$ & 23 & $\begin{array}{l}\text { Manufacturer unit operated } \\
\text { by the brand owners }\end{array}$ & Foreign owner & 47 \\
\hline Foreign owner & 22 & Domestic owner & 5 \\
\hline Domestic owner & 1 & & $\begin{array}{l}\text { Reseller trade company } \\
\text { (Selling other company's brand) }\end{array}$ \\
\hline $\begin{array}{c}\text { Reseller trade company } \\
\text { Selling other company's brand) }\end{array}$ & 6 & Foreign owner & 12 \\
\hline Foreign owner & 3 & Domestic owner & 15 \\
\hline Domestic owner & 3 & & 27 \\
\hline
\end{tabular}

Source: own editing based on empirical research

In Váci Street which is the most frequented shopping street with the highest rent figure in Hungary, $79 \%$ of the operator of the retail fashion stores were the brand owner's daughter companies itself. There was only one brand owner-manufacturer, which is Hungarian. In other shopping streets with lower rents, the composition of the stores is different in that there are more reseller companies compared to Váci street.

The difference can be noticed in fig. 1 .

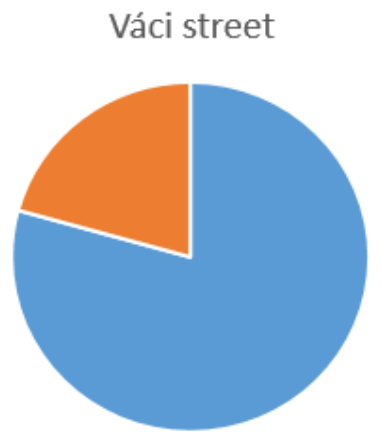

- Manufacturer- unit is operated by the brand owner
- Reseller, trade company (selling other company's brand)
Váci + Fashion + Andrássy street

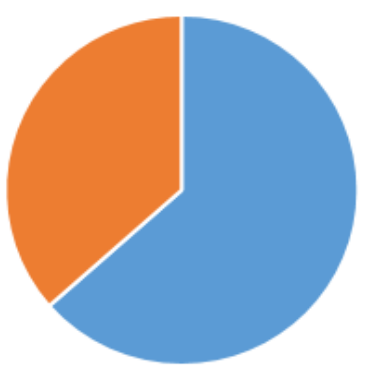

- Manufacturer- unit is operated by the brand owner

- Reseller, trade company (selling other company's brand)

Fig. 3. The Fashion retail stores composition in the high streets of Budapest source: own editing based on empirical research

In the retailing structure, there can be usually three different basic construction in the sales channel. A company can realize the whole value chain in the sales, when the firm itself is the manufacturer of the product and sells them. The profit margin is smaller when the retailer company is the importer and buys the merchandise from the brand manufacturer directly, because the manufacturer profit is missing from the chain and there is one more player in the value chain. Thirdly, the retailer buys the merchandise through a wholesale 
company or agent which stocks the merchandise from the manufacturer and realizes a smaller margin after the sales as there are 2 more players in the value chain. In order to cover the high operating and investment costs in the high streets, the sales and most importantly, the margin realized after the sales must be very high.

\section{Findings and discussion}

1) According to the results, majority of the retail stores are operated by the daughter company of the manufacturer and the one which is not a daughter company is an importer, franchise partner who buys merchandise directly from the manufacturer. Retailer who buys the merchandise from the wholesaler cannot compete in this environment, we couldn't find even one such retail unit operator firm in Váci street and Fashion Street.

2) Another finding of the research is that each of these firms found in the retail units in Váci street; the operator company itself or its parent company, has more than 30 years of experience in all cases.

3) A high level of concentration of the leading fashion companies can be noticed in the shopping streets of Budapest. Not only that many of the top 20 global leading company can be found among the 74 retail units, but also several companies are operating more than one retail stores here. For instance Inditex group operates 5 retail units in these 3 streets, H\&M operates 3. Even a smaller Hungarian reseller company operates 3 retail stores here. There are 74 fashion retail units in total, out of which 28 units are operated by 11 owners and the rest 46 units have each different owner.

4) If we match the global top 20 fashion companies with the 74 retail fashion units, (table 3 ), we can see that 10 companies out of the 20 can be found here with monolabel brand stores on these 3 shopping streets, in the unique location of Hungary. And besides the brand monolabel stores, there are many brands which also sell to other retailers, to many other multibrand stores (Adidas, Nike for example can be purchased in many multibrand stores apart from the flagship monolabel stores) and they also have other brand stores in many other retail location of the country.

Table 3: Top 20 global winner companies in the s hopping streets of Budapest

\begin{tabular}{|c|c|c|c|c|}
\hline No. & $\begin{array}{l}\text { Company } \\
\text { Name }\end{array}$ & Top 20 Company & $\begin{array}{c}\text { Present with } \\
\text { Monolabel } \\
\text { Brand Store }\end{array}$ & $\begin{array}{c}\text { Number of } \\
\text { brands in the store }\end{array}$ \\
\hline 1 & Inditex & Yes & 5 & 5 \\
\hline 2 & Nike & Yes & 1 & 1 \\
\hline 3 & LVMH & Yes & 1 & 1 \\
\hline 4 & TJX Companies & No & & \\
\hline 5 & Hermés & No & & \\
\hline 6 & H\&M & Yes & 2 & 3 \\
\hline 7 & Ricehmont & No & & \\
\hline 8 & Ross & No & & \\
\hline 9 & Adidas & Yes & 2 & 2 \\
\hline 10 & Kering & Yes & 1 & 1 \\
\hline 11 & LBrands & No & & \\
\hline 12 & Pandora & Yes & 1 & 1 \\
\hline 13 & Fast Retailing & No & & \\
\hline 14 & Next & No & & \\
\hline 15 & VF Corporation & Yes & 1 & 1 \\
\hline 16 & Luxottica & No & & \\
\hline 17 & Micheal Kors & Yes & 1 & 1 \\
\hline 18 & Gap & No & & \\
\hline 19 & Hanes Brands Inc. & No & & \\
\hline 20 & Burberry & Yes & 1 & 1 \\
\hline
\end{tabular}

Source: own editing based on empirical research 


\section{Conclusion}

This study contributed to the current knowledge on trends in the fashion retail sector by providing insights to the concentration and the factors of competition in CEEC's, focusing on the structural changes and the drivers behind this process in the main shopping streets of Budapest.

The concentration of the fashion industry has reached enormous level globally, and the Hungarian market also reflects this change. Besides the top 20 global fashion companies, some other multibrand or monobrand stores are also present in the high streets of Budapest. In most cases, only those retailers are able to operate here in this privileged area and in the highly competitive environment who have great experience in fashion retail and are able to supply their retail units from their own production, integrating the most or the whole value chain in their sales.

These results presented here are a part of an ongoing research, which have lots of limitation. The empirical research is only focusing on only one Central and Eastern European country and on only the best retail locations, the shopping streets of the capital. Further research is needed on the causes of success and failure especially in the case of domestic SME's. Investigation is needed what are the effects and results of the differences of the country specific institutional regulations.

\section{References}

BOF, McKinsey\&Company. (2018). The state of fashion 2019. https://www.mckinsey.com/ /media/McKinsey/Industries/R etail/Our\%20Insights/The $\% 20$ State $\% 20$ of $\% 20$ Fashion $\% 202$ 019\%20A\%20year\%20of\%20awakening/The-State-ofFashion-2019-final.ashx (Accessed 10 May 2019)

H\&M group: https://about.hm.com/en.html

Simonovics, I. (2015). Divat és szocializmus. Magyarország divattörténete 1945-1968. Fashion and Socialism. Hungary's fashion history 1945-1968 (in Hungarian).

Inditex https://www.inditex.com/

Kalantaridis, C. Vassilev, I., Fallon, G. (2008). The Impact of Internationalization on the Clothing Industry. in: L.Labrianidis, (Ed.), The Moving Frontier: The Changing Geography of Production in Labour Intensive Industries (pp. 149-175), Ashgate, Aldershot England.

Khan,O. (2015). Luxury consumption moves East, Journal of Fashion Marketing and Management, 19 (4): 347-359

Kering group: www.kering.com

LMVH group: www.lmvh.hu

Lopez, C., Fan Y. (2009). Internationalisation of the Spanish fashion brand Zara. Journal of Fashion Marketing and Management 13(2): 279-296

Ochkovskaya, M. (2018). Collaboration with art in the luxury industry as a marketing tool for value creation. Polish Journal of Management Studies, 18(1 p241-251

Pickles, J., Smith, A. (2011) Delocalization and persistence in the European clothing industry: the reconfiguration of trade and production networks. Regional Studies, 45(2): 167-185

Smith, A., Pickles, J., Buček, M., Pástor, R., Begg, B. (2014). The political economy of global production networks: regional industrial change and differential upgrading in the East European clothing industry. Journal of Economic Geography, 14(6): 1023-1051

Steele, V. (1988) Paris Fashion: A Cultural History. New York and Oxford: Oxford University Press.

VF corporation: https://vfcorporation.com/ t.

Dr. Maria Fekete Farkas is a professor and head of the Department for Microeconomics at the Faculty of Economics and Social Sciences, Szent Istvan University, Hungary. Her research areas are Sustainable development, Industry 4.0, new market structures and pricing. Economics of natural resources, economic, social and environment aspects of climate change, land use and renewable energy. She is member of organizing committee of several international conferences, and serves some international journals as member of editorial board, reviewer and author. Address: H-2100, Gödöllö, Páter Károly u. 1. Email address: Farkasne.Fekete.Maria@gtk.szie.hu, Phone: +3628522000

Gyorgy Gonda is $\mathrm{PhD}$ candidate at Management and Business Administration Doctoral School of Szent Istvan University, Hungary. His research area is the competitive factors of fashion retailing. He has a master degree from University of Economics, Budapest (Corvinus). Address: H-2100, Gödöllő, Páter Károly u. 1. Email address:gyorgy.gonda@gmail.com, Phone: +36 28522 000 